\title{
The Relationship Between The Number Of Cigarettes Per Day And Caffeine Intake On Headache Intensity In Faculty Of Medicine Student Batch 2016 Of Universitas Sumatera Utara
}

\author{
Muhammad Musa bin Mohd Rashid ${ }^{1}$, Alfansuri Kadri ${ }^{2}$ \\ ${ }^{1}$ College of Medicine, University of Sumatera Utara \\ ${ }^{2}$ Neurology Department, University of Sumatera Utara
}

\begin{abstract}
Headache is pain or discomfort in all areas of the head. Based on the causes, headache can be classified as primary headaches and secondary headaches. Headache can be caused by several factors such as hormones, nutrition, weather, stress, pressure, emotional, sensory problems (cigarette smoke, perfume, etc.), lack of sleep, excessive sleep, fatigue and physical activity. Cigarette smoke contains dangerous substances such as nicotine, which can cause blood vessels to become vasoconstrictive and cause headaches. Caffeine can also cause headaches. Caffeine can be consumed instead of coffee, energy drinks, cocoa and soft drinks. The aim was to determine the relationship of smoking and caffeine consumption to the intensity of headache in the 2016 USU students. To evaluate the relationship between number of cigarettes per day and caffeine intake on headache intensity in Faculty of Medicine student batch 2016 of Universitas Sumatera Utara. Analytical research methods, with cross-sectional research design on students of the 2016 University of North Sumatra School of Medicine. The study population was 227 students of the 2016 Faculty of Medicine, University of North Sumatra. The sampling method of this study was total sampling, taking the entire population of the Batch 2016 Faculty of Medicine students. All subjects were asked to fill out a questionnaire about the identity, smoking rate, level of caffeine consumption, intensity and headache frequency determined using NRS. Data analysis was made with SPSS and tested using a correlation test. Data were analyzed with the Spearman correlation test. The results show 86 respondents are male respondent $(38.1 \%)$. The female respondents were 140 respondents $(61.9 \%)$. This makes women the majority gender in this study. Then, the average age value was $21.01 \pm$ 0.048. It was found that Batak tribe respondents had the largest population, as many as 112 respondents (49.6\%). Meanwhile the Minang tribe is the least populous population of 5 respondents $(2.2 \%)$. Found respondents that smoke are 32 respondents (14.2\%). Then found respondents that did not smoke are194 respondents (85.8\%). 204 respondents consumed caffeine were around $90.3 \%$ and 22 respondents that did not consume caffeine which is about $9.7 \%$. Spearman correlation analysis test showed no significant relationship between the number of cigarettes per day and the intensity of headache $(\mathrm{p}=0.624)$ and there was a significant relationship between caffeine intake and headache intensity $(\mathrm{p}=<0.001)$. There is no relationship between the number of cigarettes per day to the headache intensity in the 2016 Faculty of Medicine students of University of North Sumatra. But there is a relationship between the number of cups of caffeine per week to headache intensity in the 2016 Faculty of Medicine students of the University of North Sumatra.
\end{abstract}

Keyword: Headache, Smoking, Nicotine, Caffeine

Received [20 Des 2019] | Revised [19 Feb 2020] | Accepted [29 Mar 2020]

\footnotetext{
*Corresponding author at: Alfansuri Kadri. Department of Neurology, Faculty of Medicine, Universitas Sumatera Utara, Medan, Indonesia. Email : alfansurikadri@yahoo.com
} 


\section{Introduction}

Cephalgia is a synonym in the medicine term for headache. The definition of headache is pain or discomfort in all areas of the head with the lower limit from the chin to the back of the head [1]. Headache is a common complaint experienced by all people. Based on the causes headache can be classified as primary headaches and secondary headaches. Primary headache is a headache that cannot be identify the anatomic abnormalities or structural abnormalities, such as migraine, tension type headache, cluster headache and other primary headaches [2].

A study found that the incidence of headache in children and adolescents was around 54.4\% [3]. Furthermore, in a study conducted at Ahvaz Jundishapur University of Medical Sciences in Iran, shows 318 subjects suffered headaches than 390 participants, about $81.53 \%$. There is a high number of headache events in medical students (Zarea, et al., 2018). This figure is almost similar to a study that was carried out at the University of North Sumatra, Indonesia that shows the prevalence of headache in medical students at the University of North Sumatra is around $78 \%$ in men and $88 \%$ in women [4].

Smoking is a major risk factor for headaches. Based on a national survey carried out in the UK, it was found that significantly people who often complained of headaches are from the group of active smokers and ex-smokers. Furthermore, based on a study in Norway, it was found that heavy smokers under the age of 40 have a higher prevalence of headaches than nonsmokers [5].

Based on data from WHO in 2015, the prevalence of 15-24 year old smoker in 2010 was around $54.6 \%$ in men and in women around 11.1\% [6]. Based on a study conducted in Europe, 2249 medical students that participated and found that 660 medical students were active smokers, which is about $29.3 \%$ [7]. Then, from a study in India, it was found that the prevalence of smokers was around 67 students (22.4\%) from total of 333 students in medical students [8]. Furthermore, a study also stated that the prevalence of smokers in medical students in Malaysia was around 69 subjects (34.5\%) of the 200 subjects chosen [9]. According to WHO data in 2011, in 2007 Indonesia ranked 5th with the largest number of smokers in the world [10]. There is a study at the Faculty of Medicine, University of North Sumatra, stating that the prevalence of smokers of medical students in 2014 was around 13.6\% [11].

Based on the research conducted by Sarker et al. (2013), several studies have shown that smoking has a significant effect on migraine. But there are also some studies that suggest that smoking has nothing to do with migraine [12].

Caffeine consumption in the world today is quite high. More than $80 \%$ of the world's population consumes caffeine every day both for stimulants, drug combinations, and to reduce jetlag in tourists. Coffee consumption as the main source of caffeine has increased by $98 \%$ in the last 10 years in Indonesia. Caffeine that works in the body can have positive effects and side effects [13]. A study states that consuming excessive caffeine can cause symptoms of headache [14]. According to the National Coffee Association of the United States in 2011, there was a $40 \%$ increase in daily coffee consumption among adolescents aged 18-24 years [15].

A research by Bawazeer and Alsobahi (2013) shows that $34.3 \%$ of energy drink drinkers containing caffeine claimed to experience side effects including palpitations, insomnia, headaches, tremors, anxiety, and nausea and vomiting. In addition, regular consumption of caffeine can cause dependence effects [16]. Based on research at Udayana University, there are $76.1 \%$ of medical students that consume caffeine and $20.2 \%$ of them experience headaches [13]. Therefore, the researcher wants to know the relationship between smoking and caffeine consumption on headache among batch 2016 FK USU students. 


\section{Method}

\section{Ethical Clearance}

The study approved by ethical committee of Fakultas Kedokteran, Universitas Sumatera Utara/RSUP H. Adam Malik, Medan with document number: 141 / TGL / KEPK / FK USURSUP HAM / 2019.

\section{Experimental Design}

This research is an analytic study, with cross sectional research design, on the 2016 Faculty of Medicine students of the Universitas Sumatera Utara.

\section{Sample and Population}

The population in this study were all 2016 Faculty of Medicine students of the University of North Sumatra. The sampling method in this study was total sampling, on 227 students of the 2016 Faculty of Medicine Universitas Sumatera Utara.

\section{Experimental Variable}

The dependent variable in this study is headache intensity. The independent variable is the number of cigarettes per day and the number of cups of caffeine per week.

\section{Operational Definition of Variable}

Headache intensity. Headache intensity scores in students that had headache in the last 3 months.

Number of Cigarettes per Day. The number of cigarettes per day smoked by students that smoke.

Number of Cups of Caffeine per Week. The number of cups of caffeine per week consumed by students.

\section{Statistical analysis}

The data obtained then processed. After the data has been processed, it is analyzed by computer using the Statistical Package for Social Science (SPSS) program and a correlation test is performed to prove the hypothesis that there is a relationship between the independent variable and the dependent variable. The degree of strength of the correlation test can be determined if the correlation value is near perfect $(r>0.8)$, strong $(0.6-0.79)$, simple $(0.4-0.59)$, weak $(r<0,4)$ [17].

\section{Result}

\section{Respondent Characteristics}

Based on the data, 86 respondents $(38.1 \%)$ were male respondent. The female respondents were 140 respondents $(61.9 \%)$. This makes women the majority of the gender in this study. Then, the mean age value was found to be $21.01 \pm 0.048$. From table 1 it is found that the tribe with the highest proportion of 112 respondents (49.6\%). Meanwhile Minang is the smallest population of 5 respondents $(2.2 \%)$. Smokers respondents were 33 respondents (14.6\%). Non-smoking respondents were 193 respondents $(85.4 \%)$.

Based on table 1, the mean value of the number of cigarettes per day found was $1.05 \pm 0.204$. Further, it was found that of 204 respondents who consumed caffeine was about $90.3 \%$. Then, a total of 22 respondents that did not consume caffeine were about 9.8\%. From table 1, 110 respondents $(48.7 \%)$ consumed coffee. This was followed by tea with a frequency of 92 
respondents $(40.7 \%)$. Then, the types of caffeine were 2 respondents $(0.8 \%)$. In the table 1 , it is found that the mean value of total cups of caffeine per week is $5.37 \pm 0.284$. The mean headache frequency was found to be $5.45 \pm 0.346$, while the mean headache intensity was 4.22 \pm 0.115 .

\section{The Correlation Between the Number of Cigarettes per Day on Headache Intensity}

Table 2 shows that the Spearman correlation test obtained a p-value of 0.624 ( $p>0.05)$ which means there is no significant relationship between the number of cigarettes per day and the headache intensity in batch 2016 Faculty of Medicine students of the Universitas Sumatera Utara.

Table 1 Demographic Characteristics

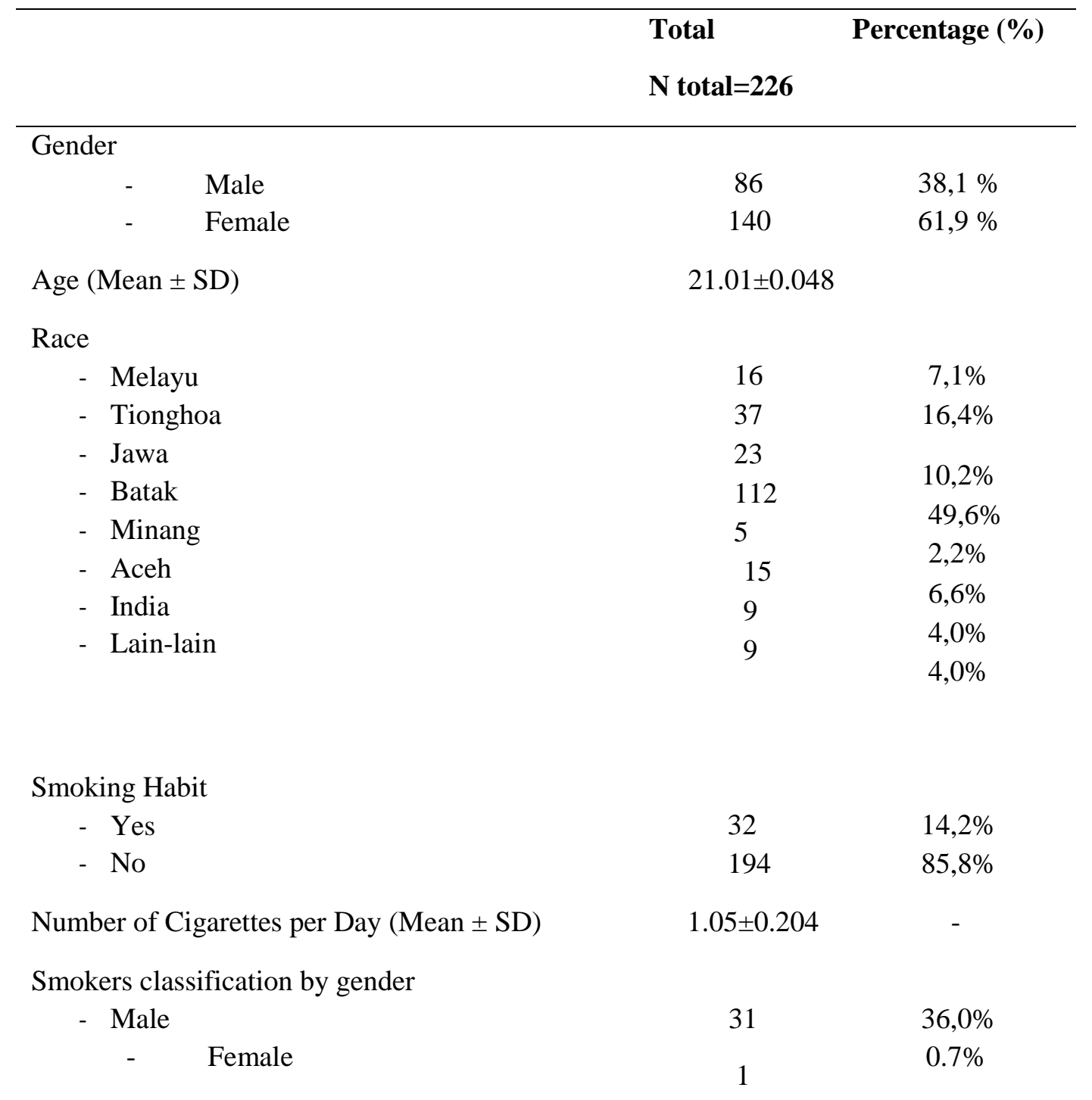

Caffeine Drinking Habit

- Yes

- No

Types of Caffeine Consumed

- Not Drink Caffeine

- Coffee

- Tea 
- Others
92

2

$5.37 \pm 0.284$

Number of Cups of Caffeine Per Week (Mean \pm $\mathrm{SD})$

Frequency of Head Pain in the Last 3 Months

(Mean $\pm \mathrm{SD}$ )

Headache intensity (NRS score) (Mean \pm SD)
$40,7 \%$

$0,9 \%$

\section{The Correlation Between the Number of Cup of Caffeine per Week on Headache Intensity}

Table 2 shows that the Spearman correlation test obtained a p value of $<0.001(p<0.05)$ which means that there is a significant relationship between the number of cups of caffeine per week and the headache intensity in batch 2016 Faculty of Medicine students of the Universitas Sumatera Utara. The correlation coefficient shows a positive outcome meaning a parallel relationship (The higher the number of cups of caffeine per week, the higher the headache intensity scores for batch 2016 Faculty of Medicine students of the Universitas Sumatera Utara. The correlation coefficient is 0.452 , which means there is a "simple correlation" between caffeine consumption and the intensity of headache among medical students batch 2016 at the Universitas Sumatera Utara.

Table 2 Correlation Results between the Number of Cups of Caffeine per Week and the Number of Cigarettes per Day with Headache Intensity

\begin{tabular}{ccc}
\hline & & Headache Intensity \\
\cline { 2 - 3 } & $\mathbf{r}$ & $\mathbf{p}(\boldsymbol{p}<\mathbf{0 , 0 5})$ \\
\hline $\begin{array}{c}\text { Number of Cup of } \\
\text { Caffeine per Week }\end{array}$ & 0,452 & $<0,001$ \\
\hline $\begin{array}{c}\text { Number of Cigarettes per } \\
\text { Day }\end{array}$ & - & 0,624 \\
\hline
\end{tabular}

\section{Discussion}

\section{Relationship Of The Number Of Cigarettes Per Day With Headache Intensity}

From the results of the study, there was no relationship between the number of cigarettes per day with the headache intensity in batch 2016 Faculty of Medicine students of the Universitas Sumatera Utara with a $\mathrm{p}$ value of 0.624 ( $\mathrm{p}>0.05$ ). This is supported by a study conducted by Ichsan Simanjuntak, concluding that there is no significant relationship between smoking habits and the intensity of headaches [18]. Then, the result also was supported by a study by Fatemah concluded that there was no significant relationship between smoking and migraine [19]. Based on research conducted by Taylor, concluded that there is no definite relationship between nicotine and headache [20]. 


\section{Relationship The Number Of Cups Of Caffeine Per Week With Headache Intensity}

From the results of the study, it was found that there was a relationship between the number of caffeine cups per week with the headache intensity batch 2016 Faculty of Medicine students of the Universitas Sumatera Utara with a $\mathrm{p}$ value of $<0.001$ ( $\mathrm{p}<0.05$ ). This is supported by a study "Caffeine and headache: specific remarks" authored by Jovel. Jovel explained that caffeine is the most consumed psychostimulant in the world. He also explained the use of caffeine can cause headaches, depression and insomnia [21]. In addition, the results of my research are also strongly supported again by research from Shimshoni. Shimshoni explained in his research that caffeine plays a role in causing headaches especially migraines. This happens because caffeine is combined with adenosine receptors which will lower glutamate activity [22]. Furthermore, in Scher's study, there was an explanation that caffeine use could be the most common risk factor in the onset of daily chronic headache [23]. However, the mechanism of the effect of caffeine consumption on headache is still unknown but there are some studies suggesting caffeine can stimulate hyperexitation of neurons in the hypothalamus and in the brain stem. This results in activation of the nociceptor pathway and neurogenic inflammation that triggers headaches [22] [21] [23].

\section{REFERENCES}

[1]. K. P. Purwandari and N. . A. Sari, "Efektifitas Massage Punggung Untuk Mengurangi Nyeri Kepala Pada Penderita Hipertensi," p. 13, 2016.

[2]. A. Akbar, "Faktor Pencetus Timbulnya Nyeri Kepala Primer Pada Mahasiswa Tingkat Akhir Program Studi Pendidikan Dokter Fakultas Kedokteran Universitas Hasanuddin," p. 1, 2017.

[3]. Ç. Wöber-Bingöl, "Epidemiology of Migraine and Headache in Children," Current pain and headache reports, vol. 17, no. 341, pp. 1-11, 2013.

[4]. H. Sjahrir, "Mekanisme Terjadinya Nyeri Kepala Primer Dan Prospek Pengobatannya," pp. 1-15, 2004.

[5]. K. . E. Waldie, R. McGee, A. . I. Reeder and R. Poulton, "Associations Between Frequent Headaches, Persistent Smoking, and Attempts to Quit," American Headache Society, vol. 48, no. 4, pp. 545-552, 2008.

[6]. M. Janah and S. Martini , "Hubungan Antara Paparan Asap Rokok Dengan Kejadian Prehipertensi," vol. 3, no. 1, pp. 1-13, 2017.

[7]. G. La Torre, W. Kirch, M. Bes-Rastrollo, R. Ramos, M. Czaplick, M. Gualano, K. Thümmler, W. Ricciardi and A. Boccia, "Tobacco use among medical students in Europe: Results of a multicentre study using the Global Health Professions Student Survey," Public Health, vol. 126, no. 2, pp. 159-164, 2012.

[8]. G. . K. S, S. SH, U. B, J. A and B. S, "Prevalence and Factors Associated with Current Smoking Among Medical Students in Coastal South India," vol. 9, no. 36, pp. 233-237, 2011. 
[9]. C. . T. Sreeramareddy, S. Suri, R. . G. Menezes, . H. . H. Kumar, M. Rahman, M. . R. Islam, . X. . V. Pereira, . M. Shah, . B. Sathian, U. Shetty and V. R. Vaswani, "Selfreported tobacco smoking practices among medical students and their perceptions towards training about tobacco smoking in medical curricula: A cross-sectional, questionnaire survey in Malaysia, India, Pakistan, Nepal, and Bangladesh," Substance Abuse Treatment, Prevention, and Policy, vol. 5, no. 29, pp. 1-9, 2010.

[10]. Y. O. G. Setyanda, D. Sulastri and Y. Lestari, "Hubungan Merokok dengan Kejadian Hipertensi pada LakiLaki Usia 35-65 Tahun di Kota Padang," no. 435, 2015.

[11]. A. Cantika, "Karakteristik Perokok Pada Mahasiswa Fakultas Kedokteran USU Angkatan 2014," pp. 1-31, 2017.

[12]. M. A. B. Sarker, M. Rahman, . M. H.-O.-. Rashid, S. Hossain, H. Kasuya, J. Sakamoto and . N. Hamajima, "Association of smoked and smokeless tobacco use with migraine: a hospital-based case-control study in Dhaka, Bangladesh," no. 4, 2013.

[13]. Liveina and A. I G A, "Pola Konsumsi Dan Efek Samping Minuman Mengandung Kafein Pada Mahasiswa Program Studi Pedidikan Dokter Fakultas Kedokteran Universitas Udayana," pp. 1-12, 2015.

[14]. C. E. Jovel and F. S. Mejía, "Caffeine and headache:specific remarks," Neurología, pp. 394-398, 2017.

[15]. K. D. Swastika, "Efek Kopi terhadap Kadar Gula Darah Post Prandial pada Mahasiswa Semester VII Fakultas Kedokteran USU Tahun 2012," pp. 1-24, 2013.

[16]. N. Bawazeer and N. Alsobahi, "Prevalence and Side Effects of Energy Drink Consumption among Medical Students at Umm Al-Qura University, Saudi Arabia," no. 104-108, 2013.

[17]. S. Sastoasmoro and S. Ismael, Dasar-Dasar Metodologi Penelitian, vol. Edition 4, jakarta: Sagung Seto, 2011.

[18]. . M. I. A. Simanjuntak, "Hubungan Kualitas Tidur dengan Intensitas dan Frekuensi Nyeri Kepala pada Mahasiswa Fakultas Kedokteran Universitas Sumatera Utara Angkatan 2014," 2014.

[19]. F. Nazari, M. Safavi and M. Muhammad, "Migraine and Its Relation with Lifestyle in Women," Pain Practice, vol. x, no. 3, 2010.

[20]. F. R. Taylor, "Tobacco, Nicotine, and Headache," American Headache Society, 2015.

[21]. C. E. Jovel and F. S. Mejia, "Caffeine and headache: specific remarks," Neurologia (English Edition), vol. 32, no. 6, pp. 394-398, 2014.

[22]. D. Shimshoni, "The Effect of Caffeine on Migraine Headache," Honors Undergraduate Theses, vol. 87, 2016.

[23]. A. Scher , W. Stewart and R. Lipton, "Caffeine as a risk factor for chronic daily headache: A population-based study," Neurology, vol. 63, no. 11, pp. 2022-2027, 2004. 